https://doi.org/10.24101/logos.2020.46

Gauta 20200521

\title{
ŽILVINAS VAREIKIS
}

Lietuvos kultūros tyrimų institutas, Lietuva

Lithuanian Culture Research Institute, Lithuania

\section{VALDŽIOS AUTORITETO PROBLEMA MACHIAVELLIO IR HAN FEIZI POLITINÉS FILOSOFIJOS KONCEPCIJOSE}

\author{
The Problem of Government Authority in the Conceptions \\ of Machiavelli and Han Feizi Political Philosophies
}

\section{SUMMARY}

The article analyzes the question of government authority based on the ideas of N. Machiavelli and Han Feizi. Both thinkers sought to establish a model of government that would justify the most pressing interests of the state. To this end, they combined the interests of government and the state as a whole, emphasizing various aspects of political philosophy. Due to the imperfections of human nature in real life, this could only partialy be accomplished. In addition to issues of social philosophical discourse, the article also explores an important intercultural perspective on these issues.

\section{SANTRAUKA}

Straipsnyje analizuojama valdžios autoriteto problema remiantis N. Machiavellio ir Han Feizi idèjomis. Abu mąstytojai stengèsi įtvirtinti tokį valdžios modeli, kuris pirmiausia pateisintų aktualiausius valstybės interesus. Siekdami šio tikslo jie, akcentuodami įvairius politinės filosofijos aspektus, valdžios ir valstybės interesus derino kaip vientisą visumą. Dèl žmogaus prigimties netobulumo realiame gyvenime tai galètų būti įvykdoma tik iš dalies. Be socialinio filosofinio diskurso klausimų, straipsnyje taip pat gvildenama svarbi tarpkultūrinè minètų klausimų svarstymo perspektyva.

\section{IVADAS}

Straipsnio autoriaus pagrindinis ty- senos bei politinių sprendimų strategiju rimo objektas - valdžios autoriteto elg- svarstymas remiantis italų Renesanso 
mąstytojo Niccolo Machiavellio (14691527) ir kinų filosofo Han Feizi (280-233 pr. Kr.) politinès filosofijos samprotavimais. Straipsnyje valdžios subjektas ir jo autoritetas traktuojamas dvejopai. Pirmiausia kaip teisiškai legitimuoto valstybès aparato veikimas su konkrečiais jai atstovaujančiais asmenimis, pateisinantis daugelio individų, kuriems atstovaujama, lūkesčius arba, atvirkščiai, nepateisinantis. Kitaip suprantamas valdžios subjektas ir jo autoritetas grindžiamas daugumos (tautos) valia ir su tuo susijusiais demo interesais. Abiem atvejais kokių nors valdžios politinių sprendimų igyvendinimas tiesiogiai priklauso nuo to, kuris valdžios subjektas - tauta ar konkretus asmuo (valdžios grupè) - turi pagrindinius politinès galios instrumentus. Iš to, kas pasakyta, kyla pagrindinis teksto tyrimo uždavinys - komparatyvistiniu rakursu išanalizuoti tautos (liaudies) ar vienvaldžio valdovo (valstybès vadovo) legitimumo bei vertybiniu valdžios aspektu dilema iš minètu tyrimo autoriu intelektiniu poziciju brëžiamos tarpkultūrinés perspektyvos. Atitinkamai iš to, kas pasakyta, kyla kertinis tyrimo tikslas ištirti, kiek galima pasitikèti teisiškai pripažintu valdžios autoritetu. Straipsnyje plètojamas politinès filosofijos problemų laukas.

\section{RELIGINIO AUTORITETO NYKIMAS}

Tautos ar valstybės vadovo pranašumo pripažinimas yra glaudžiai susijęs su dvasinėmis ar materialinèmis vertybėmis, kurių pagrindu valdžios subjektas vykdo savo funkcijas valstybejje. Straipsnio autoriaus pasirinktų dviejų skirtingiems civilizaciniams pasauliams priklausančių politinès filosofijos korifëjų - N. Machiavellio ir Han Feizi - vertybinè orientacija, iškelianti įvairiopu priemonių pasiekti politinius tikslus ambicinguma, krypsta prie materialinio pobūdžio dominantès. Skyriuje analizuojama šios tendencijos atsiradimo prielaida, kurios supratimas turi ittakos straipsnio tyrimo uždavinio, valdžios subjekto legitimumo svarstymui. Tuo tikslu straipsnio autorius, be jau minètų mąstytojų, i savo tyrinejjimo orbitą itraukia graiku filosofo Protagoro (480410 pr. Kr.) idèjinę ižvalgą.

Italų Renesanso mąstytojo Machiavellio veikale Valdovas (Il principe, 1513 m.) dėstoma absoliutaus monarcho karaliavimo koncepcija, kuri grindžiama aktualia politine praktika užuot rèmusis vien moraliniais ar ideologiniais samprotavimais. Han Feizi stiprios valstybès, paremtos baudžiamosios teisès normomis ir tvirta valdovo galia, kinų legalizmo modelis, išdèstytas 55 skyrių filosofiniame traktate, funkcionuoja kaip radikalus valstybės aparato viršenybės teigimas jo priešingybès - tautos - atžvilgiu. Tuo būdu Machiavellio ir Han Feizi filosofijose deklaruojama aiški vertybinè nuostata: silpnus valstybès narius panaudoti kaip priemones siekiant igyvendinti aukštesnius valstybès tikslus. Dèl šios priežasties, nepaisant epochos ar civilizacijų skirtumu, straipsnio autorius pastebi tam tikrą idèjini vyksma, kada valdžios autoritetas remiasi ne religinèmis priežastimis kaip senovės žydų, islamo ir iš dalies antikos graikų kultūrose, bet 
kitu šaltiniu. Koks yra pastarasis diskutuotinas šaltinis ir jo santykis su valdžios subjekto legitimumo klausimu?

Han Feizi filosofijoje prabylama apie pasaulio tvarka, kuri tiesiogiai priklauso nuo žmogaus valios. Dèl to šiam pasaulèvaizdžiui pagrissti nereikia jokios kosmologijos. Savitą pasaulio tvarkos suvokimą Han Feizi liudija vienoje iš filosofiniu istorijų. Filosofiniame naratyve komiškai vaizduojama upès dievo laukimo situacija. Žmonès mano, kad „Geltonosios upés dievas yra galingas. Karalius ji turètu sutikti. Jo tarnai karaliaus ir prašo parengti su juo susitikimą“ (Han Feizi, 2018:49). Ir žynio pareigas atliekančiam Qi karalystės suverenui paruošus altorių, išnyra ne minios lūkesčius turinti atliepti transcendentinè šventybė, o didžiulè žuvis. Han Feizi vaizduojamu pasakojimu pakankamai realistiškai teigia paprastą tiesą: gyvūnas negali būti žmogumi. Atmetus gyvūno kandidatūra, kas tuomet turètu dominuoti pasaulio tvarkoje dievybès vietoje?

Panašiu laikotarpiu gyvenęs graiku filosofas, vienas retorikos meno kūrejju Protagoras (480-410 m. pr. Kr.) aiškiai suformuluoja tezę, pagrindžiančią esminị tikrovės vertinimo matą. Anot antikos filosofijos istoriko Seksto Empiriko, perteikusio daugeli Protagoro ideju iš jo neišlikusių mokslinių traktatų, ,....jis gali tvirtinti, jog žmogus yra visų objektụ matas egzistuojančiu ir neegzistuojančių dalykų atžvilgiu. Šios tiesos jis netaikè vien reiškiniams ir taip įdiegè reliatyvizmą" (Empiricus 1988: 990). Protagoro tezè tiesiogiai papildo antitezę, kylančią iš Han Feizi filosofinès pa- rabolès. Kadangi žmogus yra pranašesnis už gyvūną, tai jis gali formuluoti etines ir teisines normas atsižvelgdamas i savo poreikius. Vadinasi, metafiziniu požiūriu Protagoro pozicija palyginime yra radikalesnè. Protagoras savo poziciją taiko visai esiniu sričiai išskirdamas žmogaus primata, o štai Han Feizi daugiau Ezopo kalba išsako savitą kritini pragmatini požiūrị i visuomeninę socialinę aplinka, persmelktą religiniu prietaru. Vis dèlto nors Han Feizi tiesmukiško verdikto patiklios minios ir miniai paklusnaus karaliaus atžvilgiu nepateikia, tačiau hipotetiškai žvelgiant i situaciją tampa akivaizdu, kad karalius atsitraukia nuo valstybės reikalu, tauta nuo savo darbu, tam tikra prasme dèl religinio spektaklio trukdoma žuviai sau ramiai pliuškentis upèje. Kitaip sakant, panašiai kaip Protagoras, tik gerokai politiškai lanksčiau Han Feizi postuluoja žmogaus pirmenybę kitu pasaulio būtybiu atžvilgiu, nepaisant to, ar individas(-ai) šią tiesą pripažista. Galiausiai kinu mąstytojas, priešingai nei Mažosios Azijos graikas, šią netiesioginę tiesą taiko pirmiausia ne metafizikai, o politikai. Suvokiama, kad pagrindinis filosofinès parabolès veikèjas yra karalius. Tik šiuo atžvilgiu Han Feizi iš išorès oru valdovo autoritetą regi kaip juokinga, kadangi jis aklai susitapatina su tautos, minios, palaikomų religiniu prietaru iliuzija.

Kitaip negu Han Feizi, kuris religijoje matè daugiau prietarus nei gilesnius vertybinius tautos būties turinius, Renesanso istorikas ir filosofas Machiavellis ¡žvelgé pozityvų religijos vaidmenį. Ma- 
chiavellis savo savitoje valstybės veikimo koncepcijoje akcentavo valstybę vienijantí religijos aspekta bet taip pat su liūdesiu apgailestavo dèl susiskaldžiusios Italijos nuolatiniu karu, kad „....niekingi žmonès mūsų religiją aiškino kaip dykinejimą, o ne dorybę" (Makiavelis 1992: 224). Kitaip sakant, Machiavellis deklaravo religijos galią aiškinti tikëjimo tiesas ir Bažnyčios kanonus, tačiau nepripažino religijos autoriteto valdant valstybę, kadangi matè, kaip supasaulèję dvasininkai savo poelgiais patys pamina religijos autoritetą. Galiausiai Machiavellio veikaluose pagrindinis valstybès subjektas, turintis spręsti jos problemas, yra valdovas, o ne dvasininkai. Valdovas turèjo padèti susiskaldžiusiai Italijai susivienyti. Siekiant šio utopinio tikslo, priešiškų Italijos suverenitetui jègu apsuptyje turëjo padèti Machiavellio siūloma valstybès valdymo moralès paradigmų kaita:

Daugelis išsigalvojo respublikas ir valstybes, nei matytas, nei girdètas tikroveje; kadangi yra didžiulis skirtumas tarp to, kas dedasi pasaulyje, ir to, kaip turètų būti, tad žmogus, priimantis norima už esama, veikiau rengia sau pražūtí, nei kuria savo gerovę, nes jis trokšdamas kas žingsnis daryti gera, prapultų tarp žmonių, nepripažistančiu gero. Užtat valdovas, norèdamas išsilaikyti soste, turi kartais būti ir blogas, ir naudotis blogiu ir gèriu - nelygu koks reikalas (Makiavelis 1992: 60).

Han Feizi filosofiniame naratyve parodomas valdovo silpnumas ir stiprybè (karalius, kuris gali būti reikšminga ir kartu juokinga persona tautos gyvenime), o Machiavellis, atvirkščiai, iš karto brèžia instrukcijas, kaip tapti stipriu monarchu, juk fortūna kaip lemties jega dažnai nepalieka laiko gilesnei refleksijai: agere considerate pluris est, quam cogitare prudenter (svarbiau yra apgalvotai veikti, negu protingai mąstyti). Panašiai kaip Machiavellis svarste romenu filosofas ir oratorius Ciceronas: „,...kad humanitas pagrindus turintis asmuo, esant galimybèms, privalo siekti palenkti likimą sau maldomis, kova, o geriausiai remiantis sumanumu ir narsumu..." (Mažeikis 2011: 60) Valdovas, ikvejptas italų mąstytojo idejju, būtent šiomis savybėmis grissdamas savo veiklą turètų lanksčiai priimti sprendimus ir, priklausomai nuo situacijos, paisyti arba nepaisyti moralinių skrupulų. Makiaveliškuoju požiūriu Qi karalystės suvereno figūra neatrodo juokinga. Aukodamas atnašas žuviai, valdovas gali tiesiog stiprinti savo valdžios autoritetą prietaringos minios akyse, o pats manyti kitaip, nepaisant pasakotojo Han Feizi ironiško žvilgsnio i vaizduojamą situaciją. Vis dèlto abieju mąstytoju atstovaujamu pozicijų atžvilgiu akivaizdu, jog religinis autoritetas nėra iki galo traktuojamas rimtai, o veikiau pritaikomas konkrečioje situacijoje taip, kad patvirtintu valstybès vadovo valdžios legitimumą. Religinio autoriteto nykimą lemia vertybiniu prioritetu pakitusi tvarka. Machiavellio ir Han Feizi filosofijose žmogus, atliekantis valdovo ar žynio pareigas, yra pirmoje vietoje, o ne Dievas ar gamta - konkretus gyvūnas. Kaip šis būties ir socialinès sandaros prioritetu paskirstymas lemia valdžios autoriteto traktavimą? 


\section{VALDŽIOS AUTORITETO IVAIZDIS}

Machiavellio ir Han Feizi filosofijose valdžios subjekto - tautos ar valstybès vadovo - legitimumas priklauso tiesiogiai nuo to, kaip formuojamas valdžios autoritetas. Kadangi šio straipsnio pagrindinis tyrimo objektas yra valdžios autoriteto problema bei jo galia atskiriems asmenims ar platesnèms žmonių masėms, straipsnio autorius skyriuje pirmiausia apibrèžia valdžios autoriteto koncepta, svarsto jo identitetą. Siekdamas kruopštesnès gvildenamo klausimo eksplikacijos, straipsnio autorius, be kertinių tyrimui personalijų, pasitelkia filosofo humanisto Ericho Frommo (19001980) idejjas, akcentuojančias individo ir valdžios autoriteto santykio peripetijas.

Reikia pripažinti, kad nepaisant tam tikrų abiejų mąstytojų teorijų skirtumų, tiek Han Feizi, tiek Machiavelliui artimos Protagoro idejjos apie žmogaus kaip visų dalykų mato visos esinijos atžvilgiu perkèlimas valdžios subjektui. Kokią itaką valdžios subjektas turi autoriteto idejos suvokimui? Han Feizi filosofinèse parabolèse pagrindiniu valdžios subjektu aiškiai įvardijamas valdovas, o atskiri tautos nariai yra viso labo jo pavaldiniai: „Valdovas yra tarsi indas. Jo pavaldiniai (min) kaip vanduo. Indas turi keturias puses, atitinkamai vanduo formuoja kvadratą. Jei indas apvalus, tada vanduo teliuskuoja apskritimo pavidalu" (Han Feizi 2018: 111-112).

Kalbama apie hierarchini santyki tarp aukštesnio rango ir žemesnio rango asmenų. Tuo būdu pirmajam atitenka lemiamas vaidmuo formuojant politikos krypti. Dèl šios priežasties šalies valdo- vas Han Feizi parabolëje apibūdinamas tarsi indas, kuris viską aprèpia. O štai žemesnio rango asmuo, atvirkščiai, tokio pasirinkimo neturi. Akivaizdu, jog jis gali tik domètis jau priimtais sprendimais ir juos vykdyti kasdienejje veikloje. Vadinasi, „indo forma“ jam yra valdovas, kuris tarsi Dievas gali lemti jo gyvenimą. Vieno asmens ar asmenų grupès diktatu tautai paremtas santykis yra būdingas daugeliui pasaulio diktatūrų Kinijoje, Šiaurès Korèjoje, Turkijoje, Irane, Rusijoje, Baltarusijoje. Han Feizi meistriškai parodo autoritarinio valdžios subjekto gebèjimą formuoti jam paklusnaus kino mentalitetą pasitelkus ivvairias priemones: numanomus pasirinkimo laisvès apribojimus ar netgi prievartos taikymą. Vokiečiuc kilmès humanistas filosofas E. Frommas veikale Žmogus sau (Man for Himself. An Inquiry into the Psychology of Ethics, 1947) toki valdžios subjekto autoritarini elgesi yra pavadinęs iracionaliu autoriteto tipu:

Iracionalaus autoriteto šaltinis... visada yra valdžia žmonėms. Ta valdžia gali būti fizinè arba protinè, reali arba sąlyginè, kylanti tik iš tam tikrų autoritetui pavaldaus žmogaus nerimo ir bejëgiškumo. Viena vertus, valdžia, kita vertus, baimè visada yra iracionalaus autoriteto atsparos. Tokiam autoritetui nereikia kritikos, bet jis ją ir draudžia... iracionalus autoritetas iš prigimties pagrịstas nelygybe, implikuojančia vertybiu skirtumą (Fromm 2008: 18-19).

Kasdienëje demokratinių valstybiu politinejje praktikoje autoritarinis valdžios subjekto elgesys yra sunkiai suvo- 
kiamas, kadangi joje savaime suprantamu dalyku yra laikomas tos šalies piliečio gebėjimas pačiam tvarkyti asmenini gyvenimą, išplaukiantis iš dažniausiai racionalaus tos šalies piliečiu santykio su valdžia. Būtent tos šalies piliečiai gerbia valdžios kompetencijas, atsižvelgia i tautos atstovų kritiką ir vertinimus. Dèl šios priežasties bet koks pasyvus paklusnumas, aklas sekimas, nesąmoningas atsidavimas aukštesnę galią turinčiam asmeniui modernioje Europoje, išskyrus Baltarusiją Rusija, kuriose vis dar vyrauja minètas iracionalus valdžios autoriteto tipas, yra tapęs svetimu laisvo žmogaus minčiai reiškiniu. Iš to, kas pasakyta, darytina išvada, kad valdžios autoritetas yra valstybès vadovo ar tam tikros valdžią turinčios žmoniu grupés pranašumas igyjamas remiantis pagarba valdžios veikimui sèkmingai spręsti šalies problemas arba, priešingai, valdžia gali būti gerbiama dèl to, jog pasitelkia jègos, prievartos veiksnius, kad išlaikytu galią tautos atžvilgiu. Iš valdžios autoriteto koncepto išplaukia, kad pirmu atveju autoriteto ịvaizdis priklauso nuo kvalifikacijos, sèkmès pasiekti užsibrèžtus tikslus, nuo lankstumo, kuri Machiavellis ivvardijo gebejimu "naudotis gèriu ir blogiu“. Antru atveju viską nulemia valdžios ambicijos ir geras sutarimas su šalies jègos struktūromis, nuo kurių priklauso autoritariniais metodais besivadovaujančios valdžios valdymo trukmè konkrečioje valstybëje. Be valdžios taikomu priemoniu, skirtu ją sustiprinti, autoriteto izvaizdi lemia valdžios subjekto tapatybè. Ar vienodai yra suvokiamas pats valdžios subjektas Han Feizi ir Machiavellio filosofijose?
Han Feizi filosofijoje valstybės vadovas ir jo funkcijų atlikimas valstybeje yra laikomas svarbiausiu dalyku, turinčiu, nors ne visada galinčiu, užtikrinti valstybės nariu gerovę. Machiavellio filosofijoje valstybès siuzereno vaidmuo šalyje traktuojamas panašiai:

...niekada nebūna arba retai kada būna taip, kad respublikoje arba karalystëje iš pat pradžių būtu įvesta gera tvarka arba, kad ta valstybe būtu visiškai pertvarkyta ir būtų atsisakyta visu senuju ỉstaigų, jeigu ją kūrẻ ne vienas žmogus. Taigi būtina, kad naują santvarką kurtų tik vienas žmogus, nuo kurio dvasios priklausytu visos naujos įstaigos. Užtat izžvalgus respublikos kūrẻjas, kurio vienintelis noras yra tarnauti ne savo, ne savo ipediniu, bet tèvynès labui, kaip įmanydamas turi stengtis pasidaryti vienvaldžiu viešpačiu (Makiavelis 1992: 122).

Remiantis Frommo mintimi, grindžiančia santykị tarp iracionalaus autoriteto tipo ir jai būdingos autoritarinès etikos, Machiavellis, taip pat ir Han Feizi pateisina valdovo tironiją. Vis dèlto kitaip nei Han Feizi pragmatinè galvosena, nukreipta i tiesioginius valdymo procesus ir skiepijanti beveik aklą pasitikëjimą autoritarine Kinijos karalystès shengren (valdytojo) valdžia, Machiavellio filosofavimą stimuliuoja tam tikra utopinè vaizduotè, grindžiama beveik mesijine viltimi, primenančia sakramentinès santuokos idejja jog valdovas išgelbės Italiją iš jos problemų ir tiek savo gyvenime susitapatins su valstybès primatu, kad valstybės reikalus spręs tarsi asmeninius. Šia prasme valstybès vadovo vaidmens interpretacija Machiavellio filosofijoje įkūnija estetiškai patrauklią 
„...puolusios / vèl igytos galios bei prarastojo rojaus alegoriją" (Airaksinen 2011: 6), kuri skiriasi nuo Apšvietos monarcho Liudviko XIV je suis l'état (valstybè - tai aš) principo, primetančio tautai daugiausia valdovo ir jo karūnuotuc valdinių ambicijas. Iš to, kas pasakyta, darytina išvada, kad valdžios autoriteto ivvaizdis priklauso tiek nuo valdžios vyk- domos politikos valdinių atžvilgiu, tiek nuo galios koncentracijos, kuri atitinkamai pagal sèkmės / nesėkmès peripetijas kasdienybejje, gali lemti valstybès dabartị ir ateiti. Galiausiai straipsnio autorius kelia prielaida, kad itakos autoriteto ivvaizdžio formavimui turi jo savita vaizduotè, nuo kurios priklauso politiniu sprendimų pagrindimas.

\section{IŠVADOS}

Apibendrinant valdžios politinio autoriteto legitimumo problemas, pirmiausia matyti, kad dabartinèse postmoderniose visuomenėse religinis mąstymas jau turi menka itaka valstybès galios suvokimui ar jos politinio potencialo stiprinimui. Šie procesai tiesiogiai siejasi su sekuliarumo postmodernioje visuomeneje isigalejjimu ir didejančia transcendentinio mąstymo fragmentacija. Antra vertus, aptariamus procesus atitinka tiek demokratinių, tiek diktatūrinių valdžių deklaracijos, skelbiančios prielankumą kuriai nors šalyje vyraujančiai religinei ideologijai ir iš jos kylančioms pastovioms vertybèms, o vykdomos politikos konkretūs sprendimai demonstruoja, priešingai, situacines vertybes ar tiesiog nebylų pritarimą paprastai stokojanti konkrečiu veiksmų realizuoti žodines deklaracijas tikrovèje. Galiausiai įvardytų tendencijų atžvilgiu Machiavellio ir Han Feizi politinès filosofijos koncepcijose atskleidžiamą religinio autoriteto nykimą ir su tuo susijusi žmogaus kaip vertybių kūrèjo iškilimą galima būtų apibūdinti kaip vieną iš galimų sniego gniūžčių laiko tèkmëje sukèlusių minètú procesų sniego laviną.
Antra, Han Feizi ir Machiavellio politinès filosofijos teorijose pateikiama stiprios valstybės koncepcija neabejotinai atstovauja pragmatiniam vertybių poliui, nors reikia pripažinti, kad pastarujuc koncepciju sukūrimo intencijos yra idealistinès. Abu mąstytojai siekè išugdyti tokią valdžia, kuri bet kokia kaina gintų objektyvius valstybès interesus. Tuo būdu abiejų mąstytojų traktatuose piešiamas valdžios autoriteto formavimas yra paremtas pasitikejjimo utopija - manymu, kad jei valdžia turès visą koncentruotą galia, ji nebus tokia savanaudè nei turèdama jos gerokai mažiau. Kaip liudija moderniujų laikų istorija, tokia mąstysena neužkerta kelio žmogaus prigimties nesaikingumui ir neapriboja valdžios žmonių savanaudiškumo - veikiau atvirkščiai, atveda prie diktatūrinių režimų tuščių lozungų ir nesèkmingu politinių sprendimų pateisinimo, vedančio šalį ir jos žmones prie didelių ūkinių ir socialinių problemų.

Trečia, abiejų mąstytojų brèžiama galios naudojimo strategiju kaita tinka tiek demokratinių, tiek diktatūrinių šalių politikai. Atitinkamai kaip Machiavellio, Han Feizi laikais, taip ir šiandien 
disponavimas galia duoda tam tikrą vertybiu laikymosi toną. Kaip antai, vykstant masiniams protestams Baltarusijoje, ivvairios pasaulio šalys išreiškè savo poziciją šiu įvykių atžvilgiu. Valstybės, kurios Baltarusiją laiko Rusijos itakos zona, deklaruoja nesikišimą į suverenios valstybès vidaus reikalus, o ivairios Vakaru šalys, iš pragmatiniu paskatu susijusios su Rusijos stambiuoju verslu, tiesiog formaliai pagrūmoja diplomatiniu kumščiu, garsiai deklaruojamu žmogaus teisių gynimu. Iš tiesų

\section{Literatūra}

Airaksinen T. 2011. Against All the Odds: Machiavelli on Fortune in Politics. Niccolo Machiavelli: galios trajektorijos, sud. L. Donskis. Vilnius: Versus Aureus.

Empiricus S. 1988. Protagoras, Les Présocratiques, sud. Jean-Paul Dumont, D. Delattre, Jean- Pau Poirier. Gallimard.

Fromm E. 2008. Žmogus sau: etikos psichologijos tyrimas. Kaunas: Verba Vera. jos nesiima kitų konkrečių veiksmų, o tylomis konformistiškai pripažista objektyviai egzistuojančią galios jègu pusiausvyra. Aptariamo konkretaus politinio konformizmo atvejo analizė eilini kartą patvirtina La Fontaine'o, Ezopo ir Krylovo pasakèčiu šiurkščią tiesą: kas turi valdžia tas disponuoja finansiniais resursais ir ivairiopai lemia tariamai laisvus vertybinius pasirinkimus. Han Feizi ir Machiavellis minètus dalykus galios atžvilgiu išsako subtilesne, mokslinių argumentų prisotinta kalba.

Han Feizi. 2018. Philosophische Fabeln. Freiburg: Herder Verlag.

Makiavelis N. 1992. Valdovas. Rinktiniai raštai. Vilnius: Mintis.

Makiavelis N. 1992. Samprotavimai apie pirmaja Tito Livijaus dekadą. Vilnius: Mintis.

Mažeikis G. 2011. Niccolo Macchiavellio fortūnos filosofija. Niccolo Machiavelli: galios trajektorijos, sud. L. Donskis. Vilnius: Versus Aureus. 